\title{
PELAKSANAAN PROGRAM NASIONAL PEMBERDAYAAN MASYARAKAT MANDIRI PERDESAAN BIDANG SIMPAN PINJAM
}

\section{Antonius}

\author{
Fakultas Ilmu Sosial dan Ilmu Politik Universitas Kapuas
}

\author{
Universitas Kapuas Sintang, Jln. Oevang Oeray No. 92 Sintang Kalimantan Barat
}

\begin{abstract}
Abstrak: Penerapan prinsip- manajemen koperasi, sosialisasi peraturan yang berkaitan dengan pelaksanaan Program PNPM-MP bidang simpan pinjam dan penyaluran kredit belum berjalan lancar. Demikian juga. Pelaksanaan Program Nasional Pemberdayaan Masyarakat Mandiri Perdesaan bidang simpan pinjam juga dipengaruhi oleh faktor internal meliputi pemahaman masyarakat yang masih rendah akan tata cara mengelola dana yang sudah di pinjam selain pegawai camat yang belum mendalam. Faktor eksternal berkaitan dengan persaingan dengan $\mathrm{CU}$ di daerah Tanah Pinoh cukup menjadi masalah bagi perkembangan kegiatan tersebut.Faktor Internal yang mempengaruhi pelaksanaan Program nasional Pemberdayaan Masyarakat Mandiri Perdesaan bidang simpan pinjam adalah pegawai masih menghadapi kendala di lapangan dan sesam petugas yang masih belum terlalu lengkap dalam memberikan penyuluhan dan sosialisasi kepada masyarakat. Sementara factor eksternal masih adanya persaingan dengan CU, belum optimalnya sosialisasi dan penyuluhan kepada masyarakat, secara rutin bagi yang sudah memenuhi syarat.
\end{abstract}

Kata Kunci : Pelaksanaan, Program Nasional Pemberdayaan Masyarakat Mandiri Perdesaan, Simpan Pinjam

Program Nasional pemberdayaan masyarakat mandiri perdesaan bidang simpan pinjam telah mengupayakan kualitas hidup manusia dan masyarakat, memperkokoh perekonomian rakyat sebagai dasar perekonomian nasional. Memajukan kesejahteraan, keadilan dan kemakmuran setiap anggota dan masyarakat pada umumnya. Kegiatan pemberdayaan ekonomi masyarakat ini telah membantu dana bagi masyarakat. Guna mengelola keuangan yang disediakan dalam bentuk sim pan pinjam dibentuklah kelompok Damai Sejahtera dan Kelompok Riga Family yang masing-masing kelompok berjumlah 15 orang dan tiap kelompok mendapat dana Rp.4.000.000,-Rp.7.000.000/ orang guna mengembangkan usaha seperti modal untuk jahit, buka kios, pembuatan tempe, tahu, sembako dan lain-lain. Setiap peminjam ketika meminjam diwajibkanb meninggalkan jaminan pinjaman berupa sertifikat tanah atau surat-surat berharga lainnya.Permasalahan yang kerap dihadapi dalam melaksanakan program nasional pemberdayaan masyarakat mandiri perdesaan bidang simpan pinjam di Desa Suka Maju Kecamatan Tanah Pinoh Kabupaten Melawi dalam meningkatkan perekonomian masyarakat antara lain adalah rendahnya kemampuan sumber daya manusia masyarakat. Dalam mengelola usahanya, program nasional pemberdayaan masyarakat mandiri perdesaan bidang simpan pinjam dirasakan masih kurang mampu dan mandiri dalam mengembangkan usahanya.Selain itu, masih rendahnyaproduktivitas program nasional pemberdayaan masyarakat mandiri perdesaan bidang simpan pinjam.

Berbagai masalah struktural masih dihadapi program ini. Berupa terbatasnya sumber-sumber pembiayaan modal kerja, fasilitas kredit, termasuk pula kurangnya akses untuk memperoleh layanan pengembangan bisnis dan dukungan jaringan pemasaran, menjadi penyebab rendahnya produktivitas program nasional pemberdayaan masyarakat mandiri perdesaan bidang simpan pinjam.Permasalahan lainnya adalah belum optimalnya pembinaan pada masyarakat terhadap makna dan tujuan diadakannya kegiatan program nasional pemberdayaan masyarakat mandiri perdesaan bidang simpan pinjam. Kurangnya kemampuan dan pengetahuan masyarakat akan kewirausahaan menjadi persoalan krusial yang dihadapi, terutama kemampuan dan penguasaan jaringan usaha/bisnis dan informasi pengembangan usaha. Dampak dari semuanya ini menyebabkan lambannya gerak perputaran bisnis masyarakat.

Berangkat dari penjelasan masalah pada latar belakang, penulis tertarik membahas masalah dengan judul" Pelaksanaan program nasional pemberdayaan masyarakat mandiri perdesaan bidang simpan pinjam di Desa Suka Maju Kecamatan Tanah Pinoh Kabupaten Melawi.Prinsip-prinsip Program Nasional Pemberdayaan Masyarakat Mandiri Perdesaan bidang simpan pinjam, dimuat dalam UndangUndang Nomor 25 Tahun 1992 Tentang Perkoperasian, dimana Program Nasional Pemberdayan Masyarakat Mandiri Perdesaan 
bidang simpan pinjam melaksanakan prinsip koperasi sebagai berikut: (1) keanggotaan bersifat sukarela dan terbuka; (2) pengelolaan dilakukan secara demokratis; (3) pembagian sisa hasil usaha dilakukan secara adil sebanding dengan besarnya jasa usaha masing-masing;(4) pemberian balas jasa yang terbatas terhadap modal; dan kemandirian dalam mengembangkan koperasi”. Setiap usahamasyarakat baik skala kecil dan menengah mempunyai masalah yang berbeda, demikian juga manajemen harus disesuaikan dengan situasi masing-masing yang bersangkutan karena setiap usaha, usaha kecil dan menengah mempunyai kekuatan-kekuatan, kelemahan-kelemahan dan tantangan-tantangan tersendiri. Oleh karena itu manajemen memegang peranan yang penting, tidak saja disektor pemerintahan, perusahaan, dan lainlain bahkan setiap ibu rumah tangga dan kepala rumah tangganya dengan baik, bagaimana merencanakan uang yang diperoleh untuk keperluan keluarga.

Menurut Pudiklatwas BPKP (2000:86) "semua orang tahu mengenai keberhasilan dan kejatuhan suatu organisasi dan semua orang juga tahu penyebabnya adalah manajemen. Walaupun kita tahu bahwa ada faktor yangtidak dapat dikendalikan". Hal itulah pentingnya manajemen yang secara minimal dapat mengeliminasi faktorfaktor yang tidak dapat dikendalikan.Menurut Wijaya (2005:11) "manajemen adalah ilmu dan seni yang merupakan proses kegiatan usaha menyatukan pemikiran-pemikiran, bahan-bahan, uang dan orang-orang untuk menghasilkan dan memasarkan produk yang lebih tinggi atau memberikan pelayananuntuk mencapai keuntungan". Dari pengertian tersebut menurut Wijaya (2005:12) ada tiga (3) tujuan yang sama dan sangat penting bagi manajemen, yakni : "1) tujuan yang khusus dan misi dari lembaga, seperti perusahaan, rumah sakit dan lain-lain, 2) membuat kerja produktif dan bekerja yang berorientasi kepada pencapaian tujuan, dan 3) pengelola yang mempunyai pengaruh dan tanggung jawab sosial". Menurut Wijaya (2005:15) ada lima (5) fungsi dasar yang dilaksanakan oleh para pengelola yaitu perencanaan, pengorganisasian, pengisian staf, pengarahan, dan pengawasan. Menurut Wijaya (2005:21) "pada prinsipnya tujuan manajemen yaitu memelihara dan meningkatkan kesejahteraan anggota, melalui peningkatan kemampuan organisasi, pelayanan umum dan peningkatan kegiatan usaha". Manajemen dalam Program Nasional Pemberdayaan Masyarakat Mandiri Perdesaan bidang simpan pinjam memiliki karakteristik tersendiri dan berbeda dengan model kapitalistik, karena cita-cita dan nilai-nilai yang dikandungkan dan karenanya sistemProgram Nasional Pemberdayan Masyarakat Mandiri Perdesaan bidang simpan pinjam adalah tidak bebas nilai.

Manajemen ini didasarkan pada kebersamaan yang dalam persi Indonesia diberikan karakteristik kebersamaan dan kegotong-royongan. Wijaya (2005:23) menyatakan karakteristik manajemen Program Nasional Pemberdayan Masyarakat Mandiri bidang simpan pinjam adalah sebagai berikut: "(1) tujuan kegiatannya jelas, (2) pengurusnya terbuka untuk mengadakan komunikasi, (3) kerja sama, (4) keputusan diambil bersama, (5) pengembangan inisiatif, (6) saling membantu, (7) objektif dan realitis, dan (8) evaluasi".Bagaimana Program Nasional Mandiri Mandiri Perdesaan bidang simpan pinjam dapat dituntut untuk dapat melayani kepentingan ekonomi anggota secara optimal, kalau usaha tersebut tidak dikelola secara efisien dan efektif. Menurut Wijaya (2005:91) "memang Program Nasional Pemberdayaan Masyarakat Mandiri Perdesaan bidang simpan pinjam dibentuk bukan pertama bermotif mencari keuntungan tetapi Program Nasional Pemberdayaan Masyarakat Mandiri Perdesaan bidang simpan pinjam dibentuk dengan motif memberikan layanan". Motif layanan ini sebagai konsekuensi watak sosial yang dimiliki oleh sebagai badan usaha. Dengan layanan ekonomi oleh Program Nasional Pemberdayaan Masyarakat Mandiri Perdesaan bidang simpan pinjam kepada anggota, maka layanan ekonomi tersebut dapat memecahkan masalah ekonomi bersama yang dihadapi oleh anggota.

Sasaran umum Program Nasional Pemebrdayaan Masyarakat Mandiri Perdesaanbidang simpan pinjam dalam lima tahun mendatang adalah: (1) Meningkatnya kemampuan usaha masyarakat, (2) Meningatnya jumlah masyarakat yang menanamkan modalsehingga semakin produktif, dan (3) Meningkatnya kewirausahaan masyarakat dan tumbuhnya wirausaha baru. Untuk mewujudkan sasaran tersebut, menurut Kantor Program Nasional Pemberdayaan Masyarakat Mandiri Perdesaan bidang simpan pinjamKecamatan Tanah Pinoh Kabupaten Melawi (2005:22) pemberdayaan kegiatan bidang simpan pinjam akan dilaksanakan dengan arah kebijakan sebagai berikut: (1) Megembangkan lingkungan usaha yang kondusif untuk PNPM-MP bidang simpan pinjam, melalui peningkatan kelembagaan dan manajemen usaha, (2) Meningkatkan dan memperluas akses program PNPM-MP bidang simpan pinjam kepada sumberdaya produktif, melalui dukungan lembaga keuangan mikro dan perluasan sumber-sumber 
pembiayaan PNPM-MP bidang simpan pinjam, (3) Menumbuhkan sikap kewirausahaan, melalui penguatan lembaga pelatihan dan peningkatan kualitas usaha bagi wirausaha baru.Selain itu dalam upaya mendukung kesinambungan dan peningkatan pelaksanaan pembangunan yang pesat seiring dengan kemajuan pembangunan di Indonesia dan perkembangan internasional serta sejalan dengan peningkatan tuntutan kebutuhan masyarakat,maka pemerintah terus menggalakan yang bisa menopang usaha kecil dan menengah. Dalam menjalankan usahanya sebagai lembaga perekonomian, kegiatan sehari-hari tidak akan terlepas dari bidang keuangan, yaitu menghimpun dana dari masyarakat melalui simpanan dan menyalurkan dana yang dihimpun tersebut dalam bentuk kredit atau pinjaman. Menurut Wijaya (2005:21) "peranan koperasi perlu ditingkatkan sesuai dengan fungsinya dalam menghimpun dan menyalurkan kepada masyarakat dengan lebih memperhatikan pembiayaan kegiatan sektor perekonomian nasional tanpa diskriminasi sehingga akan memperkuat struktur perekonomian nasional".Dalam melaksanakan program nasional pemberdayaan masyarakat mandiri perdesaan bidang simpan pinjam, bertitik tolak seperti yang dimuat dalam Undang-Undang Nomor 25 Tahun 1992 Tentang Perkoperasian, dimanaProgram Nasional Pemberdayan Masyarakat Mandiri Perdesaan bidang simpan pinjam melaksanakan prinsip koperasi sebagai berikut: keanggotaan bersifat sukarela dan terbuka; pengelolaan dilakukan secara demokratis; pembagian sisa hasil usaha dilakukan secara adil sebanding dengan besarnya jasa usaha masing-masing;pemberian balas jasa yang terbatas terhadap modal; dan kemandirian dalam mengembangkan koperasi, maka PNPM-MP Kecamatan Tanah Pinoh melaksanakan pula prinsip koperasi sebagai berikut: pendidikan perkoperasian serta kerja sama antar koperasi.

$$
\text { Menurut Wijaya, (2005:32) }
$$

terkonsentrasinya usaha program Nasional Pemberdayaan Masyarakat Mandiri Perdesan bidang simpan pinjam dalam penyaluran kredit oleh beberapa alasan yaitu;Sifat usaha Program Nasional Pemberdayaan Masyarakat mandiri Perdesaan bidang Simpan Pinjam yang berfungsi sebagai lembaga intermediasi antar unit surplus dan unit defisit.Penyaluran kredit memberikan selisih (spread) yang pasti sehingga besarnya pendapatan bunga dapat diperkirakan.Sumber dana Program Nasional Pemberdayaan Masyarakat Mandiri Perdesaan bidang Simpan Pinjam berasal dari dana pemerintah sehingga secara moral mereka harus menyalurkan kembali kepada masyarakat dalam dalam bentuk penyaluran kredit (menggerakan roda perekonomian). Oleh sebab itu untuk memperoleh keyakinan dalam penyaluran kredit, sebelum memberikan simpan pinjam harus melakkukan penilaian yang saksama terhadap watak, kemampuan, modal, prospek usaha, serta agunan, maka peranan analisis kredit adalah untuk memperoleh keyakinan atas kemampuan dan kesanggupan peminjam untuk melunasi seluruh kewajibanyasesuai dengan yang telah menjadi kesepakatan. Untuk itu pemahaman tentang analisis kredit bagi petugas/pejabat yang terkait dalam proses putusan kredit sangat penting untuk menunjang kelancaran penyelesaian suatu permohonan kredit dan melaksanakan azas prinsip kehati-hatian dan azas pemberian kredit yang sehat.Dalam penyaluran kredit memungkinkan terjadinya gagal bayar atau default yang menyebabkan timbulnya tunggakan atau kredit macet.

Menurut Anderson(1988:66) "adanya dukungan masyarakat sangat dipengaruhi beberapa faktor seperti respek terhadap otoritas pemerintahan, kesadaran dan keyakinan, sistem nilai, kepentingan pribadi, sanksi hukum dan masalah waktu".Jika berbagai faktor itu positif dalam arti baik maka tingkat dukungan masyarakat akan tinggi, begitu pula jika sebaliknya. Sebab menurutTangkilisan 2003:14) mencatat "ada beberapa kriteria yang menjadi indikator keberhasilan implementasi kebijakan yang satu diantaranya adalah kepuasan target group". Kepuasan target group ini akan berpengaruh dan dipengaruhi oleh sikap kesediaan mereka menerima dan berpartisipasi dalam implementasi kebijakan tersebut.

\section{METODE}

Jenis dalam penelitian ini adalah menggunakan rancangan penelitian deskriptif. Sesuai dengan tujuan dari pada penelitian ini adalah untuk menggambarkan Pelaksanan program nasional pemberdayaan masyarakat mandiri bidang simpan pinjam dengan subjek penelitian dalam penelitian ini adalah:Camat, Kecamatan Tanah Pinoh Kabupaten Melawi, Pegawai Kantor Kecamatan Tanah Pinoh Bidang Program Nasional Pemberdayaan Msyarakat Mandiri Perdesaan dan Ketua Kelompok Simpan Pinjam Khusus Perempuan (SPP). Teknik pengumpulan data yang dilakukan melalui Wawancara, Observasi dan Studi dokumentasi. alatpengumpilan data sebagai berikut:Pedoman wawancara. Catatan lapangan dan Dokumen. Untuk menganalisis data yang diperoleh, teknik yang dipergunakan penulis adalah teknis analisis data secara kualitatif. Penelitian ini berlokasi di Kantor Desa Suka Maju Kecamatan 
Tanah Pinoh Kabupaten Melawi. Alasan pemilihan lokasi tersebut, adalah sebagai berikut:

\section{HASIL PENELITIAN DAN PEMBAHASAN}

Program Nasional Pemberdayaan Masyarakat Mandiri perdesaan adalah program Nasional Pemerintah Indonesia yang ditujukan untuk meningkatkan kesejahteraan masyarakat pedesaan melalui perluasan kesempatan dan penciptaan lapangan kerja dan tambahan pendapatan rumah tangga miskin, serta memperkuat kelembagaan pembangunan partisipatif melalui pendekatan pemberdayaan masyarakat dan peningkatan kinerja pemerintah lokal yang baik dalam rangka pengentasan kemiskinan.

Hasil wawancara dengan anggota simpan pinjam mengatakan bahwa peran serta PNPM Mandiri Perdesaan dalam penanganan masalah kemiskinan melalui pemberdayaan ekonomi masyarakat, telah dilakukan di berbagai tempat termasuk di Desa Suka Maju Kecamatan tanah Pinoh Kabupaten Melawi. Pengalaman pananganan pasca gempa seperti di atas, merupakan pengalaman yang dapat dipertanggungjawabkan sehingga PNPM Mandiri Perdesaan dapat menangani hal-hal yang diperuntukan bagi pengem,bangan usaha masyarakat.Hasil wawancara dengan Camat Tanah Pinoh diperoleh informasi bahwa tujuan program Nasional Pemberdayaan Masyarakat Mandiri Perdesaan tersebut adalah:(1) Memperkuat/menghidupkan kembali organisasi/ kelembagaan masyarakat agar dapat segera memulai kembali kegiatan kehidupan individual/ keluarga/ rumahtangga dan kelompok/ sosial mereka, melalui kegiatan program secara partisipatif, padat karya, berdiskusi dan bermusyawarah bersama untuk memutuskan jenis aktivitas serta melaksanakan kegiatan pembangunan rehabilitasi yang bermanfaat bagi kepentingan hidup bersama; (2) Menumbuhkan dan memulihkan kembali kepercayaan masyarakat untuk membangun kembali kehidupan mereka; (3) Mendanai kegiatan pembangunan sarana/ prasarana skala menengah-kecil atau lingkup desa dan fasilitas sosial-umum lainnya.

Memberikan sumber pendapatan sementara/ penyangga bagi keluarga/ rumah tangga melalui pembayaran Hari Orang Kerja (HOK) dari pelaksanaan kegiatan pembangunan, serta melalui pinjaman bergulir modal usaha kelompok perempuan. (4) Meningkatkan Partisipasi masyarakat, termasuk masyarakat miskin, kelompok perempuan, komunitas adat terpencil, dan kelompok masyarakat lainnya yang rentan dan sering terpinggirkan ke dalam proses pengambilan keputusan dan pengelolaan pembangunan, (5) Meningkatkan kapasitas kelembagaan masyarakat yang mengakar, representative dan akuntabel, (6) Meningkatkan kapasitas pemerintah dalam memberikan pelayanan kepada masyarakat terutama masyarakat miskin melalui kebijakan, program dan penganggaran yang berpihak pada masyarakat miskin, (7) Meningkatkan sinergi masyarakat, pemerintah daerah, swasta, asoiasi, perguruan tinggi, lembaga swadaya masyarakat, organisasi masyarakat dan kelompok peduli masyarakat lainnya, (8) Meningkatkan keberdayaan dan kemandirian masyarakat, serta kapasitas pemerintah daerah dan kelompok peduli setempat dalam menanggulangi kemiskinan di wilayahnya, (9) Meningkatkannya modal social masyarakat yang berkembang sesuai dengan potensial dan budaya untuk melestarikan kearifan local, (10) Meningkatnya inovasi dan pemanfaatan teknologi tepat guna, informasi dan komunikasi dalam pemberdayaan masyarakat.

Prinsip yang diutamakan adalah: 1) Partisipatif, artinya dalam setiap tahapan proses (perencanaan, pelaksanaan dan pertanggungjawaban) selalu melibatkan masyarakat sebagai pelaku sekaligus penerima manfaat, 2) Transparan dan 3) Akuntabel, artinya dalam setiap langkah dan kegiatan harus dilakukan secara terbuka dan dapat dipertanggunghawabkan kepada masyarakat luas. 4) Sederhana, artinya pelaksanaan seluruh proses kegiatan diupayakan sederhana dan bisa dilakukan masyarakat dengan tetap mengacu pada tujuan dan ketentuan dasar pelaksanaan program rehabilitasi ini. 5) Akuntabilitas, artinya seluruh proses palaksanaan dan pendanaan dilakukan dengan penuh tanggung jawab.Permasalahan kemiskinan yang cukup kompleks membutuhkan intervensi semua pihak secara bersama dan terkoordinasi. Namun penanganannya selama ini cenderung parsial dan tidak berkelanjutan.

Peran dunia usaha dan masyarakat pada umumnya juga belum optimal. Kerelawanan sosial dalam kehidupan masyarakat yang dapat menjadi sumber penting pemberdayaan dan pemecahan akar permasalahan kemiskinan juga mulai luntur. Untuk itu diperlukan perubahan yang bersifat sistemik dan menyeluruh dalam upaya penanggulangan kemiskinan.Untuk meningkatkan efektivitas penanggulangan kemiskinan dan penciptaan lapangan kerja, pemerintah meluncurkan program nasional pemberdayaan masyarakat (PNPM) Mandiri mulai tahun 2009. Melalui PNPM Mandiri dirumuskan kembali mekanisme upaya 
penanggulangan kemiskinan yang melibatkan unsur masyarakat, mulai dari tahap perencanaan, terutama masyarakat miskin, dapat ditumbuh kembangkan sehingga mereka bukan sebagai obyek melainkan subyek upaya penanggulangan kemiskinan.Pelaksanaan PNPM Mandiri tahun 2009 dimulai dengan dua program pemberdayaan masyarakat, yaitu program pengembangan kecamatan (PPK) sebagai dasar pemberdayaan masyarakat di perdesaan, dan program penanggulangan kemiskinan diperkotaan (P2KP) sebagai dasar bagi pengambangan pemberdayaan masyerakat di perkotaan.Mulai tahun 2009 PNPM Mandiri diperluas dengan melibatkan program pengembangan daerah tertinggal dan khusus (P2DTK) untuk pengambangan daerah tertinggal, pasca bencana dan konflik; dan program pengambangan infrastruktur sosial ekonomi wilayah (PISEW) untuk mengintegrasikan pusatpusat pertumbuhan ekonomi dengan daerah sekitarnya.

PNPM jga diperkuat dengan berbagai program pemberdayaan masyarakat yang dilaksanakan oleh berbagai departemen sektor.Dengan pengintegrasian berbagai program pemberdayaan masyarakatke dalam kerangka kebijakan PNPM Mandiri, cakupan pembangunan diharapkan dapat diperluas hingga ke daerahdaerah terpencil dan terisolir.Program Nasional Pemberdayaan Masyarakat Mandiri Perdesaan bidang simpan pinjam mempunyai ciri-ciri utama yakni, menggunakan pendekatan partisipatif masyarakat, melakukan penguatan kapasitas kelembagaan masyarakat dan kegiatan program dilaksanakan secara swakelola oleh masyarakat.

Hasil wawancara dengan ketua kelompokSimpan Pinjam khusus perempuan penerapan prinsip manajemen koperasi pada program Nasional Pemberdayaan Masyarakat Mandiri Perdesaan Bidang Simpan Pinjam Desa Suka Maju berkaitan dengan pertumbuhan dan perkembangan simpan pinjam yang semakin meningkat, hal ini dapat dilihat dari jumlah asset dan anggota yang semakin bertambah. Perlunya penerapan prinsip manajemen koperasi adalah karena semakin meningkatnya pendapatan petani karet di wilayah kerja Desa Suka Maju, kesadaran masyarakat akan pentingnya menyimpan dan meminjam merupakan wadah peningkatan ekonomi keluarga serta adanya penempatan karyawan yang lebih intensif.Salah satu prinsip manajemen koperasi adalah perencanaan yang telah disusun pada awal tahun buku 2009 merupakan pedoman dalam melaksanakan kegiatan program kerja badan pengawas 2010 adalah pemeriksaan fisik kas dan buku tabungan setiap bulan, pemeriksaan bidang perkreditan setiap bulan serta mengikuti peltihan atau pendidikan oleh Departemen Koperasi atau lembaga relevan lainnya. Rencana kerja Program Nasional Pemberdayaan Masyarakat Mandiri Perdesaan Bidang Simpan Pinjam tahun 2009 antara lain adalah peningkatan pelayanan kepada anggota. Pada tahun 2009 untuk meningkatkan daya saing maka dianggap perlu meningkatkan kualitas dan kuantitas pelayanan kepada anggota dan perluasan wilayah kerja.Korwil atau yang disebut Penganggungjawab Operasional Kegiatan (PJOK) juga berfungsi sebagai nara sumber bagi tim kredit. Sedangkan karyawan sebagai titik tumpu dari kepengurusan sehingga rencana kerja yang telah ditetapkan serta dituangkan dalam program kerja, dapat dilaksanakan untuk mencapai tujuan. Absensi kerja perlu ditingkatkan dan penuh tanggung jawab.Untuk aspek koordinasi, program kerja menjadi tanggung jawab semua pihak, baik pengurus maupun karyawan, oleh sebab itu koordinasi internal antar personil pengurus, karyawan, serta unsur-unsur terkait lainnya baik vertikal maupun horisontal mutlak sangat diperlukan. Koordinasi juga merupakan benteng pertahanan internal untuk mengantisipasi tantangan eksternal bagi suatu lembaga dalam era persaingan pasar secara sehat.

Dibentuknya koordinator wilayah (korwil) yang disebut Penanggungjawab operasional kegiatan (PJOK) adalah wujud nyata dilapangan sebagai perpanjangan tangan/ujung tombak suatui lembaga, dalam wujud koordinasi antar anggota serta anggota terhadap lembaga. Dengan demikian informasi, aspirasi, ide serta motivasi dapat terserap serta terseleksi secara positif.Prinsip manajemen koperasi dilakukan juga melalui pengawasan, yaitu dengan pemeriksaan pembukuan. Dengan adanya tanggung jawab masing-masing kelihatan pembukuan secara umu baik kekeliruan yang ada diperbaiki setelah dikordinasikan kepada yang bersangkutan. Pemeriksaan pembukuan dilaksanakan secara rutin sekali dalam setiap bulan.

Sarana pengendalian karyawan/pengurus berupa komponen-komponen pembagian tugas setiap bagian. Evaluasi kinerja karyawan/pengurus berupa seperangkat kriteria dengan pokok tujuan memotivasi karyawan/pengurus serta staf lainnya di dalam loyalitas terhadap lembaga rasa memiliki, serta tanggung jawab.Arti penting penerapan prinsip manajemen koperasi pada Program Nasional Pemberdayaan Masyarakat Mandiri Perdesaan Bidang Simpan Pinjam antara lain adalah karena semakin meningkatnya pendapatan petani karet di wilayah kerja, kesadaran masyarakat 
akan pentingnya koperasi merupakan wadah peningkatan ekonomi keluarga serta adanya penempatan karyawan di lapangan sebagai unit pengelola kegiatan (UPK) ternyata pelayanan terhadap anggota lebih Intensif. Salah satu prinsip manajemen koperasi dalah perencanaan. Perencanaan yang telah disusun pada awal tahun buku merupakan pedoman dalam melaksanakan kegiatan.

Penerapan prinsip manajemen koperasi juga berkaitan dengan organisasi dan karyawan serta koordinasi. Struktur kepengurusan dibentuk sesuai dengan keperluan simpan pinjam berkaitan dengan perkembangan jumlah anggota yang berdomisili di berbagai tempat. Untuk aspek koordinasi, program kerja menjadi tanggung jawab semua pihak, baik pengurus maupun karyawan, oleh sebab itu koordinasi internal antar personil pengurus, karyawan, serta unsur-unsur terkait lainnya baik vertikal maupun horizontal mutlak sangat diperlukan. Prinsip manajemen dan koperasi dilakukan juga melalui pengawasan, yaitu dengan pemeriksaan pembukuan. Dengan adanya tanggung jawab masing-masing kelihatan pembukuan secara umum baik kekeliruan yang ada diperbaiki setelah dikoordinasikan kepada yang bersangkutan. Pemeriksaan pembukuan dilaksanakan secara rutin sekali dalam setiap bulan. Sarana pengendalian karyawan/pengurus berupa komponen-komponen pembagian tugas setip bagian.

Evaluasi kinerja karyawan/pengurus berupa seperangkat kriteria dengan pokok tujuan memotivasi karyawan/pengurus serta staf lainnya di dalam loyalitas terhadap lembaga, rasa memiliki, serta tanggung jawab.Tersusunnya rencana penggunaan DOK Perencanaan Peserta MAD Sosialisasi terdiri dari: a). Enam orang wakil per desa: Kepala desa, 2 orang wakil dari BPD/nama lain yang sejenis (jika sudah ada), dan 3 orang tokoh masyarakat (sekurangkurangnya 3 dari keenam wakil tersebut adalah perempuan) dari semua desa di kecamatan. (b). Unsur-unsur yang dapat dipilih mewakili desa untuk hadir dalam MAD adalah: Kades, BPD atau sebutan lainnya, Lembaga Pemberdayaan Masyarakat (LPM), Wakil RTM dari setiap desa, Wakil perempuan dari setiap desa, Anggota Komite sekolah, Lembaga Swadaya Masyarakat (LSM)/Organisasi Massa (ormas), Tokoh masyarakat, tokoh agama, Anggota masyarakat lainnya. Dalam MAD Sosialisasi juga dihadiri oleh Camat dan staf terkait, wakil instansi sektoral kecamatan (ISK) maupun terbuka untuk anggota masyarakat lainnya yang berminat. Sebagai narasumber dalam pertemuan MAD Sosialisai adalah:TK PNPM Mandiri Perdesaan
Kabupaten, Camat dan Instansi tingkat Petunjuk Teknis Operasional PNPM Mandiri Perdesaan kecamatan terkait. Sedangkan fasilitator pertemuan adalah: PjOK/PjAK, UPK dan FK/FT.

Sumber pendanaan berasal stimulan dana operasional kegiatan (DOK) dari PNPM Mandiri Perdesaan dan swadaya desa dan/atau kecamatan. Dokumen yang dihasilkan adalah: Berita Acara yang menuangkan hasil-hasil keputusan musyawarah. Jadwal musyawarah desa sosialisasi Rencana Penggunaan DOK Perencanaan. Selain itu terdap[at Musyawarah Desa (Musdes) Sosialisasi Musdes sosialisasi merupakan pertemuan masyarakat desa sebagai ajang sosialisasi atau penyebarluasan informasi PNPM Mandiri Perdesaan di desa.

Hasil yang diharapkan dalam musdes sosialisasi adalah sebagai berikut: a). Tersosialisasinya informasi pokok PNPM Mandiri Perdesaan meliputi: tujuan, prinsip, kebijakan, pendanaan, organisasi, proses dan prosedur yang dilakukan kepada masyarakat desa, b). Dipahaminya kebijakan tentang pemetaan RTM, pembentukan BKAD, penanganan masalah, pemantauan, pemeriksaan dan evaluasi, pola penyampaian informasi, c). Tersosialisasinya keputusan yang dihasilkan dalam musyawarah antar desa sosialisasi, d). Adanya pernyataan kesanggupan atau kesedian desa untuk mematuhi danmelaksanakan ketentuan PNPM Mandiri Perdesaan, e). Terpilihnya Pengurus TPK terdiri dari; Ketua, Sekretaris, dan Bendahara, f). Tersosialisasinya konsep dan kebijakan, perencanaan kegiatan dengan pola Menggagas Masa Depan Desa (MMDD) sebagai dasar penyusunan RPJMDes. g). Tersosialisasikannya pola pemantauan, pemeriksaan, dan evaluasi, h). Ditetapkannya BPD sebagai lembaga pengawas pelaksanaan PNPM Mandiri Perdesaan di desa. i). Dibentuk tim pemantau dari unsur masyarakat untuk melakukan pemantauan pelaksanaan kegiatan. J). Dipilih dan ditetapkannya KPMD atau kader desa dan kader teknik yang akan memfasilitasi masyarakat dalam menyelenggarakan proses PNPM Mandiri Perdesaan, k). Disepakati dan ditetapkannya jadwal musyawarah desa perencanaan, 1). Disepakati pembuatan dan lokasi pemasangan papan informasi PNPM Mandiri Perdesaan dan media informasi lainnya. Peserta Musdes Sosialisasi terdiri dari: a). Kepala desa dan aparat desa, b). BPD atau sebutan lainnya, c). Lembaga Pemberdayaan Masyarakat (LPM), d). Wakil RTM desa, e). Wakil perempuan, f). LSM/ ormas, g). Tokoh masyarakat, tokoh agama, h). Anggota masyarakat lainnya yang berminat untuk hadir. 
Tahap awal dalam pelaksanaan program Nasional Pemberdayaan Masyarakat Mandiri Perdesaan bidang simpan pinjam adalah mensosialisasikan dan memberikan penyuluhan mengenai program yang ada kepada seluruh lapisan masyarakat program simpan pinjam yang disosialisasikan adalah simpanan deposito bulanan.Penyaluran dana dimengerti sebagai proses penyaluran dana BLM dari Kantor Pelayanan Perbendaharaan Negara (KPPN) atau Kas Daerah ke rekening kolektif BLM yang dikelola oleh UPK.

Mekanisme penyaluran dana BLM sebagai berikut: Penyaluran dana yang berasal dari pemerintah pusat mengikuti ketentuan yang diatur dalam Peraturan Direktur Jenderal Anggaran, Depkeu (b). Penyaluran dana yang berasal dari Pemerintah Daerah, dilakukan melaui mekanisme APBD dan diatur dalam Peraturan Direktur Jenderal Perbendaharaan, Depkeu (c). Dana yang berasal dari APBD harus disalurkan terlebih dahulu ke masyarakat, selanjutnya diikuti dengan penyaluran dana yang berasal dari APBN (d). Besaran dana dari APBD yang disalurkan ke masyarakat harus utuh tidak termasuk pajak, retribusi atau biaya lainnya. Pencairan dana adalah proses pencairan dari rekening kolektif BLM yang dikelola Unit Pengelola Kegiatan (UPK) kepada Tim Pengelola Kegiatan di di desa. Mekanisme pencairan dana sebagai berikut: (a)Pembuatan surat perjanjian pemberian bantuan antara UPK dengan TPK (b). TPK menyiapkan Rencana Penggunaan Dana sesuai kebutuhan dilampiri dengan dokumendokumen perencanaan kegiatan(c). Untuk pencairan berikutnya dilengkapi dengan Laporan Penggunaan Dana sebelumnya dan dilengkapi dengan buktibukti yang sah. Faktor internal yang mempengaruhi program Nasional Pemberdayaan Masyarakat Mandiri Perdesaan Bidang Simpan Pinjam dalam mengambangan perekonomian masyarakat di Desa Suka Maju diantaranya adalah kurangnya pemahaman pengurus, pengawas, dan staf terhadap fungsi dan tugas masing-masing. Pada tahun buku 2010 , sering terjadi kesalah pahaman antara pengurus, pengurus dan staf terhadap fungsi, tugas dan wewenang masing-masing komponen. Diharapkan pada tahun 2011 masing-masing komponen dapat memahami tugas masing-masing dengan lebih baik.Faktor internal lainnya adalah karyawan tidak disiplin.

Hambatan yang cukup besar yang dirasakan adalah karyawan dalam pelaksanaan tugas sehari-hari sering tidak masuk kerja, tanpa alasan sebagai akibatnya aktifitas dikantor terlambat, tugas-tugas yang diberikan tidak selesai dan tidak tuntas.Secara internal juga pemehaman anggota terhadap koperasi masih rendah/kurang akibat masih rendahnya pemehaman anggota terhadap aturan sering terjadi anggota setelah meminjam tidak melakukan ansuran pinjaman. Akibat uang yang akan dipinjamkan kepada anggota lain menjadi berkurang dan terpaksa diadakan penagihan kepada anggota yang bermasalah.Kurangnya tenaga lapangan juga mempengaruhi pelaksanaan PNPM-MP dalam mengembangan perekonomian masyarakat di Desa Suka maju Kecamatan tanah pinoh.

Dalam pengembangan program bidang simpanm pinjam tahun buku 2009 salah satunya adalah kurangnya tenaga lapangan yang ditugaskan untuk mengambil setoran anggota dan melakukan penagihan anggota yang bermasalah. Hambatan yang cukup besar yang dirasakan adalah karyawan dalam pelaksanaan tugas sehari-hari sering tidak masuk kerja, tanpa alasan sebagai akibatnya aktifitas di kator terhambat, tugas-tugas yang diberikan tidak selesai dan tidak tuntas.Secara internal juga pemahaman anggota terhadap program simpan pinjam masih rendah/kurang. Akibat masih rendahnya pemahaman anggota terhadap aturan sering terjadi anggota setelah meminjam tidak melakukan angsuran pinjaman. Akibatnya uang yang akan dipinjamkan kepada anggota laing menjadi berkurang dan terpaksa diadakan penagihan kepada anggota yang bermasalah.

Kurangnya tenaga lapangan juga mempengaruhi program Nasional Pemberdayaan Masyarakat Mandiri Perdesaan Bidang Simpan Pinjam dalam mengembangan perekonomian masyarakat didesa Suka maju yang ditugaskan untuk mengambil setoran anggota dan melakukan penagihan anggota yang bermasalah.Dalam upaya pengembangan program Nasional Pemberdayaan Masyarakat Mandiri Perdesaan bidang simpan pinjam terdapat kendala yang kadang kadang terjadi di lapangan adalah adanya gesekan antara pengelola kegiatan yang dilakukan oleh petugas lapangan, memprovokasi anggota dengan tujuan mengalihkan keanggotaan dari kegiatan yang bersangkutan. Secara eksternalperan penanggungjawab operasional kegiatan dalam mengembangan perekonomian masyarakat di Desa Suka Maju adalah pembinaan yang intensif dari instansi terkait.Dalam upaya pengembangan simpan pinjam, peranan instansi terkait sangat kami rasakan manfaatnya terutama dalam bentuk pelatihanpelatihan yang diada oleh Kantor Desa Suka Maju. Pelatihan tersebut dapat menambah wawasan dan pengetahuan kami dalam pengembangan program. Faktor eksternal lainnya adalah peningkatan ekonomi masyarakat yang cukup tinggi. Akibat pertumbuhan ekonomi masyarakat yang cukup tinggi, disertai kesadaran manfaat menabung dari masyarakat pedesaan. 
Secara eksternal faktor yang mempengaruhi peran kegiatan simpan pinjam dalam mengembangan perekonomian masyarakat di desa pelimping kecamatan Tanah Pinoh adalah adanya persaingan dengan CU lainnya. Dalam upaya pengembangan PNPM-MP kendala yang kadangkadang terjadi di lapangan adalah adanya gesekan antara koperasi yang dilakukan oleh petugas lapangan koparasi tertentu, memprovokasi anggota dengan tujuan mengalihkan keanggotaan dari PNPM-MP ke (CU) yang bersangkutan. Secara eksternal peran PNPM-MP bidang simpan pinjam dalam mengembangan perekonomian masyarakat didesa Suka Maju adalah pembinaan yang intensif dari instansi terkait.Dalam upaya pengembangan ekonomi dan usaha, peranan instansi terkait sangat kami rasakan manfaatnya terutama dalam bentuk pelatihan-pelatihan yang diadakan oleh kantor PNPM-MP bidang simpan pinjam. Pelatihan tersebut dapat menambah wawasan dan pengetahuan kami dalam pengembangan perkriditan. Faktor eksternal lainnya adalah peningkatan ekonomi masyarakat yang cukup tinggi.

\section{KESIMPULAN DAN SARAN}

Berdasarkan hasil penelitian dan pembahasan penulis dapat menyimpulkan bahwa:Tata cara pelaksanaan Program Nasional Pemberdayaan Masyarakat Mandiri Perdesaan Bidang Simpan Pinjam dalam mengembangan perekonomian masyarakat di desaDesa Suka Maju adalah dengan menerapkan prinsip manajemen koperasi, sosialisasi dan penyuluhan dan memberikan bantuan pinjamn berupa penyaluran kredir. Prinsip manajemen koperasi yang diterapkan adalah perencanaan, organisasi dan karyawan, koordinasi, serta melalui pengawasan. Pelaksanaan sosialisasi belum dapat berjalan optimal, karena belum menjangkau seluruh lapisan masyarakat. Selain itu kegiatan penyuluhan dan sosialisasi bari dilakukan sekitar Desa Suka Maju saja.

Faktor Yang mempengaruhi pelaksanaan Program nasional mandiri Perdesaan Bidang
Simpan Pinjam meliputi: faktor internal yang mempengaruhi peran PNPM-MP bidang simpan pinjam dalam mengembanganperekonomian masyarakat di Desa Suka Maju diantaranya adalah kurangnyapemahaman pengurus, pengawas, dan staf terhadap fungsi dan tugas masing-masing. Sering terjadi kesalah pahaman antara pengurus, pengawas dan staf terhadap fungsi, tugas dan wewenang masing-masing komponen. Faktor internal lainnya adalah karyawan tidak disiplin. Hambatan yang cukup besar yang dirasakan adalah karyawan dalam pelaksanaan tugas sehari-hari sering tidak masuk kerja, tanpa alasan sebagai akibatnya aktifitas di kantor terhambat, tugas-tugas diberikan tidak selesai dan tidak tuntas. Secara internal juga pemahaman anggota terhadap koperasi masih rendah/kurang. Kurangnya tenaga lapangan juga mempengaruhi peran PNPM-MP bidang simpan pinjam dalam mengembangan perekonomian masyarakat di desa pelimping kecamatan kelam permai yang ditugaskan untuk mengambil setoran anggota dan melakukan penagihan anggota yang bermasalah. Secara eksternal faktor yang mempengaruhi PNPMMPbidang simpan pinjam adalah adanya persaingan dengan CU lainnya.

Diharapkan tata cara pelaksanaan Program Nasional Pemberdayaan Masyarakat Mandiri Perdesaan bidang simpan pinjam belum berjalan lancar seperti penerapan prinsip manajemen koperasi yang belum berhasil baik, sosialisasi dan penyuluhan kurang berjalan mulus termasuk penyaluran kredit. diharapkan untuk mencairkan pinjaman kepada anggota yang sudah memenuhi persyaratan dengan sistem antrian, dan disesuaikan dengan uang yang terkumpul setiap bulannya. Sehingga anggota merasa benar-benar bisa memenfaatkan uang sesuai dengan keinginan dan uang yang mereka terima bisa digunakan dengan sebaik mungkin. Sebagai pengendalian dan pengawasan perlu diadakan evaluasi kinerja dengan semakin banyaknya karyawan terlibat, diharapkan persaingan dengan hasil yang diperoleh secara perorangan dalam kriteria bagus. 
185 Fokus, Volume 17, Nomor 2, September 2019, hlm. hlm. 177 - 185

\section{DAFTAR PUSTAKA}

Arifin, NJ. 2004. Analisa Kredit. Jakarta: Media Komunikasi Pekerja BRI Unit.

Badudu, J.S. dan Zain Sm. 1996. Kamus Umum Bahasa Indonesia. Jakarta: Pustaka Sinar Harapan.

Handoko T.H. 2000. Manajemen (Edisis 2). Yogyakarta:BPFE.

Hirujito, 2001. Fungsi-Fungsi Manajemen Perkantoran. PT.Remaja Rosdakarya

Islamy, M.I. 1988. Materi Pokok Kebijakan Publik. Jakarta: Karunika UT.

Kantor Koperasi dan Usaha Kecil Menengah (UKM) Kabupaten Melawi 2005. Rencana Strategi Tahun 2006-2010.

Mile Hubberman2014. Metode Penelitian Kualitatif. Bandung: PT. Remaja Rosdakarya.
Pudiklatwas BPKP. 2000. Sitem Pengendalian Manajemen. Jakarta. Granit

Rencana Pembanguna Jangka Menengah Kabupaten Melawi Tahun 2006-2010 (tidak diterbitkan)

Siagian, SP. 1988. Administrasi Pembangunan; Konsep, Dimensi Dan Strateginya. Jakarta: CV Haji Mas Agung.

Tangkilisan, H.N. 2003. Implementasi Kebijakan Publik, Transformasi Pikiran George Edwards. Yogyakarta: Lukan Ofset.

Udang-Undang Nomor 25 Tahun 1992 Tentang Perkoperasian

UNKA, 2017. Buku Pedoman Skripsi. Sintang: Universitas Kapuas.

Wijaya, A. 2005. Manajemen Koperasi. Malang: Bina Manajemen Koperasi Usaha Kecil Indonesia. 